\title{
Effect of Water Saving Irrigation Management Practices on Rice Productivity and Methane Emission from Paddy Field
}

\author{
Hafsa Jahan Hiya, Muhammad Aslam Ali*, Md. Abdul Baten, Sanjit Chandra Barman \\ Department of Environmental Science, Bangladesh Agricultural University, Mymensingh, Bangladesh \\ Email: *aslam.envs@bau.edu.bd, *litonaslam@yahoo.com
}

How to cite this paper: Hiya, H. J., Ali, M. A., Baten, M. A., \& Barman, S. C. (2020). Effect of Water Saving Irrigation Management Practices on Rice Productivity and Methane Emission from Paddy Field. Journal of Geoscience and Environment Protection, 8, 182-196.

https://doi.org/10.4236/gep.2020.89011

Received: August 31, 2020

Accepted: September 27, 2020

Published: September 30, 2020

Copyright $\odot 2020$ by author(s) and Scientific Research Publishing Inc. This work is licensed under the Creative Commons Attribution International License (CC BY 4.0).

http://creativecommons.org/licenses/by/4.0/

(c) $\underset{\mathrm{By}}{\text { (i) Open Access }}$

\begin{abstract}
Irrigation water supply is one of the vital components for sustainable rice farming, which is becoming a limiting resource in the changing climatic condition. An experiment was conducted at the research field of Bangladesh Agricultural University, Mymensingh during dry season from January-June of 2017 to investigate the suitability of Alternate Wet and Dry Irrigation (AWDI) for sustainable rice production and reducing methane emission. The modern rice variety BINA Dhan 10 was used as test crop. There were five irrigation treatments viz. $\mathrm{T}_{1}$ (saturated condition), $\mathrm{T}_{2}$ (continuous flooded, 5 $\mathrm{cm}$ standing water), $\mathrm{T}_{3}$ (AWDI-10 cm; irrigated when water level fell $10 \mathrm{~cm}$ from surface), $\mathrm{T}_{4}$ (AWDI-15 cm; irrigated when water level fell $15 \mathrm{~cm}$ from surface) and $\mathrm{T}_{5}$ (AWDI- $20 \mathrm{~cm}$; irrigated when water level fell $20 \mathrm{~cm}$ from surface). Results of the field trial showed satisfactory grain yield and low seasonal methane emission along with significantly high irrigation water savings (\%) in AWDI treated field plots. Among the treatments, $\mathrm{T}_{3}(\mathrm{AWDI}-10 \mathrm{~cm}$ ) and $\mathrm{T}_{4}$ (AWDI-15 cm) showed higher yield performance $\left(6250 \mathrm{~kg} \cdot \mathrm{ha}^{-1}\right.$ and $5810 \mathrm{~kg} \cdot \mathrm{ha}{ }^{-1}$, respectively) with lower $\mathrm{CH}_{4}$ emission (reduced up to $36 \%$ and $40 \%$, respectively) compared to continuous flooded treatment (T2, CF $5 \mathrm{~cm}$ water). In AWDI field plots less irrigation frequency $(6-9)$ was required which significantly saved the amount of irrigation water $(12 \%-24 \%)$. Although $\mathrm{T}_{5}$ (AWDI-20 cm) showed the highest water savings (24\%) and lowest $\mathrm{CH}_{4}$ emission (reduced up to 50\%); however the lowest grain yield (4283 $\mathrm{kg} \cdot \mathrm{ha}^{-1}$ ) was found under this treatment. On the other hand, continuously irrigated (T2, $5 \mathrm{~cm}$ standing water) field plot showed lower yield (4783 $\left.\mathrm{kg} \cdot \mathrm{ha}^{-1}\right)$ but significantly higher methane emissions compared to other treatments during rice cultivation. Water productivity index was also found higher in AWDI treated field plots compared to continuously irrigated field plot. At the
\end{abstract}

${ }^{\star}$ Corresponding author. 
reproductive stage of rice plant well-developed aerenchyma tissue was observed in root cortex under the continuous irrigated field plot, which indicates higher diffusion pathway of methane gas from root rhizosphere to the atmosphere compared to other treatments. Therefore, alternate wet and dry irrigation water management practice may be recommended at farmers' level for sustainable rice production and reducing methane emission during dry winter Boro season which will reduce the cost of production by water saving as well as energy saving.

\section{Keywords}

Water Saving, AWDI, CH4, GWP, Rice Paddy

\section{Introduction}

Global agriculture in 21st century faces the tremendous challenge of providing sufficient and healthy food for growing population under increasing water scarcity, while minimizing environmental consequences. In agriculture sector, rice is a major food grain crop in the world and it will be necessary to produce about $60 \%$ more rice than currently produced to meet food demands by 2025. In Bangladesh, rice is the prime food grain crop cultivated in $77 \%$ (28.49 million hectares) of the total cropped area that covers 5th largest position of the world in respect to rice cultivation area (BBS, 2012). But rice cultivation especially in dry winter (Rabi) season requires huge amount of irrigation water, which is a great challenge due to energy crisis. From the time immemorial, rice is grown in low land areas under continuous flooding in Asian tropics and subtropics that requires between 700 and $1500 \mathrm{~mm}$ water per cropping season depending on soil texture (Bhuiyan, 1992) that leads to high surface runoff, seepage and percolation account for between $50 \%-80 \%$ of total water input. Water availability in Bangladesh is around 90 billion cubic meters (BCM) during dry season against the demand of $147 \mathrm{BCM}$, a shortage of nearly $40 \%$, resulting in drought situation in large parts of the country (Quassem, 2010). Boro rice in Bangladesh is fully irrigated and the Aman rice is partly irrigated. An estimated 3000 to 5000 litres of water is required to produce one $\mathrm{kg}$ rice (BRRI, 2016). So, Bangladesh is going to face severe water crisis within next couple of decades. In future, it will be necessary to produce more food with less water or increase the efficiency of water management. Again, flooded rice cultivation is a major anthropogenic source of methane $\left(\mathrm{CH}_{4}\right)$ which is one of the important greenhouse gases having 25 times more global warming potential than carbon dioxide (Nieder \& Benbi, 2008). These flooded soils characterized by low oxygen and high organic substrates offering an ideal environment for methanogen bacteria generate anaerobic condition that favors $\mathrm{CH}_{4}$ production as an end product from organic matter degradation (Conrad, 2002). Methane from soil is derived from C mineralization, moisture, $\mathrm{pH}$, soil Eh, etc. and emitted to the atmosphere by molecular diffusion, ebul- 
lition or plant mediated transport like aerenchyma (Zheng et al., 2007). The $\mathrm{CH}_{4}$ concentration in the atmosphere has reached $1.77 \mathrm{ppm}$ by volume in 2005, which is more than double that of its preindustrial value (Solomon et al., 2007). Therefore, it is necessary to solve water scarcity and minimizing $\mathrm{CH}_{4}$ emission from rice paddy without aggravating rice production.

Two main types of water efficient irrigation practiced in Bangladesh are: 1) Alternate Wetting and Drying (AWD) and 2) System of Rice Intensification (SRI). AWDI developed by International Rice Research Institute, is a water saving and methane mitigation technology where rice fields are not kept continuously submerged but are allowed to dry intermittently during growing stages. But a severe AWD regime in where photosynthesis is severely inhibited and plants cannot rehydrate overnight could markedly decrease grain yield, although it reduces methane emission from paddy fields (Win et al., 2015). Again, SRI is an efficient, resource-saving and productive way to practice the use of younger rice seedlings planted singly at wider spacing, together with intermittent irrigation and organic fertilization adoption. In our country, it is difficult to follow SRI because of some limitations like organic fertilization and more laborious that sum up more cost (Uphoff \& Kassam, 2009). On the contrary, alternate wetting and drying irrigation for rice has become popular in Bangladesh than SRI due to economic and environmental feasibility (Price et al., 2013). Although, few studies in Bangladesh showed the effect of AWDI on rice yield, they do not give us a clear idea to sketch out the effect of AWDI on rice yield and $\mathrm{CH}_{4}$ emission during rice cultivation. Therefore, this research experiment was conducted to evaluate different water saving irrigation management practices in paddy field for mitigating methane emissions and sustaining rice productivity.

\section{Materials and Methods}

\subsection{Experimental Field Preparation and Rice Cultivation}

The experiment was carried out at the research field of Bangladesh Agricultural University in 2017. The soil of experimental site was well drained, loamy texture having a soil $\mathrm{pH}$ (6.43) with moderate organic matter (1.78), $0.17 \%$ total nitrogen, $13.9 \mathrm{ppm}$ available phosphorous and $16.3 \mathrm{ppm}$ available potassium. The experimental field had three side-by-side blocks for three replications and each plot $\left(20 \mathrm{~m}^{2}\right)$ was laid down in a randomized complete block design where block to block and plot to plot distances were $1.5 \mathrm{~m}$ and $1 \mathrm{~m}$ to prevent interactions. The field was tilled with a tractor and subsequently ploughed and cross ploughed followed by laddering and cleaning. These plots were surrounded by $25 \mathrm{~cm}$ wide and $20 \mathrm{~cm}$ high levees separated by $1 \mathrm{~m}$ transition zones. The applied fertilizer doses were Urea $220 \mathrm{~kg} \cdot \mathrm{ha}^{-1}$, TSP $115 \mathrm{~kg} \cdot \mathrm{ha}^{-1}$, MoP $100 \mathrm{~kg} \cdot \mathrm{ha}^{-1}$ and Gypsum 60 $\mathrm{kg} \cdot \mathrm{ha}^{-1}$. Among them, nitrogenous fertilizer (urea) was applied thrice as basal dose after transplantation, whereas others were applied only once before transplanting. Rice seedlings (21 days old BINA Dhan 10) were transplanted into ex- 
perimental plots at three seedlings hill ${ }^{-1}$ with $25 \mathrm{~cm} \times 20 \mathrm{~cm}$ spacing between the rows and hills, respectively.

\subsection{Placement of Perforated Pipes According to Treatments}

In this study, five irrigation treatments were followed: $\mathrm{T}_{1}=$ Saturated, $\mathrm{T}_{2}=$ Continuous flooding ( $5 \mathrm{~cm}$ standing water), $\mathrm{T}_{3}=A W D I, 5 \mathrm{~cm}$ irrigation applied when water level in the pipe fell $10 \mathrm{~cm}$ below ground level, $\mathrm{T}_{4}=\mathrm{AWDI}, 5 \mathrm{~cm}$ irrigation applied when water level in the pipe fell $15 \mathrm{~cm}$ below ground level and $\mathrm{T}_{5}=\mathrm{AWDI}, 5 \mathrm{~cm}$ irrigation applied when water level in the pipe fell $20 \mathrm{~cm}$ below ground level. Perforated PVC pipes were installed in the experimental plots 10 days after transplanting (DAT) according to treatments for measuring soil water depletion to follow AWDI techniques. The diameter of pipe was $8 \mathrm{~cm}$ and the lengths were $25 \mathrm{~cm}, 30 \mathrm{~cm}$ and $35 \mathrm{~cm}$, respectively. After irrigation had been applied, water entered through perforations and water levels inside the pipe were at same level as that of outside. With the progress of time, water got depleted in AWDI plots, but a close observation revealed that there was water inside the pipe and again $5 \mathrm{~cm}$ irrigation was done when the depleting water table inside the pipe reached a certain level from ground soil.

\subsection{Determination of Effective Rainfall, Crop Water Requirement and Water Savings}

Effective rainfall was estimated by USDA Soil Conservation Method (Smith, 1992).

$$
\text { 1) } \left.P \text { effective }=\frac{P \text { total }(1.25-0.2 \times P \text { total })}{125} \text { (when, } P \text { total }<250 \text { min. }\right)
$$

2) $P$ effective $=125+0.1 \times P$ total (when, $P$ total $>250$ win $)$ where, $P$ effective $=$ effective rainfall $(\mathrm{mm})$ and $P$ total $=$ total rainfall $(\mathrm{mm})$.

Total rainfall data of cropping period of that year was collected from the department of Irrigation and Water Management, Bangladesh Agricultural University. Again, water requirements for rice cultivation was computed by adding applied irrigation water, effective rainfall during growing season and water for land preparation (Rashid, 1997). In the study, water saving percentage was calculated as follows:

$$
\begin{aligned}
& \text { Water Savings }(\%) \\
& =\frac{\text { Water supplied in flooded plot }- \text { Water supplied in AWDI plot }}{\text { Water supplied in flooded plot }} \times 100
\end{aligned}
$$

Water loss was calculated based on water amount supplied in each plot.

\subsection{Gas Sampling, Analysis and Estimation of $\mathrm{CH}_{4}$ Emission}

A closed-chamber method (Ali et al., 2008) was used to estimate $\mathrm{CH}_{4}$ emission during rice cultivation. Gas samples were collected by $50 \mathrm{ml}$ gas-tight syringes at 0,15 and 30 minutes after chamber placement over flooded plots at different rice growth stages to get average $\mathrm{CH}_{4}$ emissions. The dimension of closed chamber 
was $62 \mathrm{~cm} \times 62 \mathrm{~cm} \times 112 \mathrm{~cm}$. Samples were analyzed to determine $\mathrm{CH}_{4}$ concentration by gas chromatograph (Shimadzu, GC 2014, Japan) with a Flame Ionization Detector. The temperatures of column, injector and detector were adjusted at $100^{\circ} \mathrm{C}, 200^{\circ} \mathrm{C}$ and $200^{\circ} \mathrm{C}$, respectively. A closed-chamber equation (Rolston, 1986) was used to estimate methane fluxes for every treatment.

$$
F=\rho \times V / A \times \Delta c / \Delta t \times 273 / T
$$

where, $F($ Flux $)=\mathrm{CH}_{4}$ emission rate $\left(\mathrm{mg} \mathrm{CH}_{4} \mathrm{~m}^{-2} \cdot \mathrm{hr}^{-1}\right), \rho=$ gas density $(0.714$ $\left.\mathrm{mg} \cdot \mathrm{cm}^{-3}\right), V=$ volume of chamber $\left(A \times h ; \mathrm{m}^{3}\right), A=$ surface area of chamber (length $\times$ width; $\left.\mathrm{m}^{2}\right), h=$ height of the chamber $(\mathrm{m}), \Delta c / \Delta t=$ rate of increase of $\mathrm{CH}_{4}$ gas concentration $\left(\mathrm{mg} \cdot \mathrm{m}^{-3} \cdot \mathrm{hr}^{-1}\right), T$ (absolute temperature $)=273+$ mean temperature $\left({ }^{\circ} \mathrm{C}\right)$.

Total methane flux for the entire cropping period was computed by the formula (Singh et al., 1999):

$$
\text { Total } \mathrm{CH}_{4} \text { flux }=\sum_{i=1}^{n}\left(R_{i} \times D_{i}\right),
$$

where, $R_{i}=$ rate of methane flux $\left(\mathrm{g} \cdot \mathrm{m}^{-2} \cdot \mathrm{d}^{-1}\right)$ in the $i$ th sampling interval, and $n=$ number of sampling intervals.

\subsection{Estimation GWP of $\mathrm{CH}_{4}$}

To estimate the GWP, $\mathrm{CO}_{2}$ is typically taken as the reference gas, and an increase or reduction in emission of $\mathrm{CH}_{4}$ is converted into " $\mathrm{CO}_{2}$-equivalents" by means of their GWPs. In this study, we used the IPCC factors to calculate the combined GWP for 100 years $\left(\mathrm{GWP}=25 \times \mathrm{CH}_{4}, \mathrm{~kg} \mathrm{CO}_{2}\right.$-equivalents ha-1) from $\mathrm{CH}_{4}$ under various agricultural irrigation practices. In addition, the greenhouse gas intensity (GHGI) was calculated by dividing GWP by grain yield for rice (Mosier et al., 2006).

\subsection{Explorations of Rice Plant Growth and Yield}

Rice plant growth parameters like plant height, root length were investigated during different growing period. Again, $4-5 \mathrm{~cm}$ long root samples collected at reproductive stage were conserved in proper tagged glass tubes (with FA solutions) for free hand sectioning to show anatomical view whether aerenchyma developed or not under a scanning electron microscope. Yield components such as panicle number per hill and grain numbers per panicle were determined at harvesting stage. When 95\% grains became yellow, harvesting was done. After harvesting, crops were separately collected, bundled and tagged for threshing. Finally, the grains were sun dried up to $14 \%$ moisture content, then weighed as $\mathrm{kg} \cdot \mathrm{ha}^{-1}$.

\subsection{Estimation of Water Productivity Index}

Water productivity index is the ratio of crop yield $(\mathrm{kg} / \mathrm{ha})$ per unit water $\left(\mathrm{m}^{3} / \mathrm{ha}\right)$ supplied (Jaafar et al., 2000) and calculated as follows: 


$$
\text { Water productivity index }\left(\mathrm{kg} / \mathrm{m}^{3}\right)=\frac{\text { Grain Yield }(\mathrm{kg} / \mathrm{ha})}{\text { Total water supplied }\left(\mathrm{m}^{3} / \mathrm{ha}\right)}
$$

\subsection{Investigation of Soil Properties}

Soil redox potential (Eh) were measured during rice cultivation at certain time intervals by glass electrode Eh meter. At harvesting stage, soil bulk density (BD) was analyzed using cores (volume $100 \mathrm{~cm}^{3}$, inner diameter $5 \mathrm{~cm}$ ), filled with fresh moisture soils. The collected core samples were oven dried at $105^{\circ} \mathrm{C}$ for 24 $\mathrm{h}$ and then measured the weight of dried core samples. Soil porosity was calculated using $\mathrm{BD}$ and particle density $\left(\mathrm{PD}, 2.89 \mathrm{Mg} \cdot \mathrm{m}^{-3}\right.$ ) according to the equation:

$$
\text { porosity }(\%)=(1-\mathrm{BD} / \mathrm{PD}) \times 100
$$

At harvesting stage, chemical properties of the collected soil samples were analyzed for organic carbon by wet oxidation method (Walkley \& Black, 1965), organic matter content by multiplying the percent organic carbon with Van Bemmlen factor of 1.73, total nitrogen by Micro-kjeldhal method (Page et al., 1982), available phosphorus by Olsen method (Olsen et al., 1954), exchangeable potassium by Flame photometer (Brown \& Lilleland, 1946).

\subsection{Statistical Analysis}

The compiled and tabulated data of rice growth, yield, soil properties and $\mathrm{CH}_{4}$ emission were statistically analyzed by Analysis of Variance (ANOVA) to examine whether treatment effects were significant or not. The mean differences among treatments were compared by Duncan's Multiple Range Test. The computer software MSTAT-C was used for statistical analysis.

\section{Results}

\subsection{Effect of Irrigation Managements on $\mathrm{CH}_{4}$ Emission during Rice Growing Season}

The different irrigation managements significantly influenced on $\mathrm{CH}_{4}$ emission from paddy field at all stages of growing season (Figure 1). Although, $\mathrm{CH}_{4}$ emission rate showed increasing trend from the very beginning of growing stage, suddenly fluctuated at active tillering stage (42 DAT), then gradually increased onwards and sharply increased from panicle initiation stage (56 DAT), peaked at flowering stage (84 DAT) and finally dropped at grain maturation stage (91 - 105 DAT) for all irrigation systems. In study, the highest $\mathrm{CH}_{4}$ peak was detected in continuous flooded plots and the lowest emission was in AWDI plots. Among AWDI plots, $\mathrm{T}_{3}(10 \mathrm{~cm})$ showed comparatively higher $\mathrm{CH}_{4}$ flux than $\mathrm{T}_{4}(15 \mathrm{~cm})$ and $\mathrm{T}_{5}(20 \mathrm{~cm})$. Different considerable factors influencing $\mathrm{CH}_{4}$ emission are given below:

A negative correlation was observed between soil $\mathrm{Eh}$ and $\mathrm{CH}_{4}$ emission rate. It was found that soil redox potential significantly decreased by advancement of growth stage and AWDI treatments showed less soil Eh reduction than other 


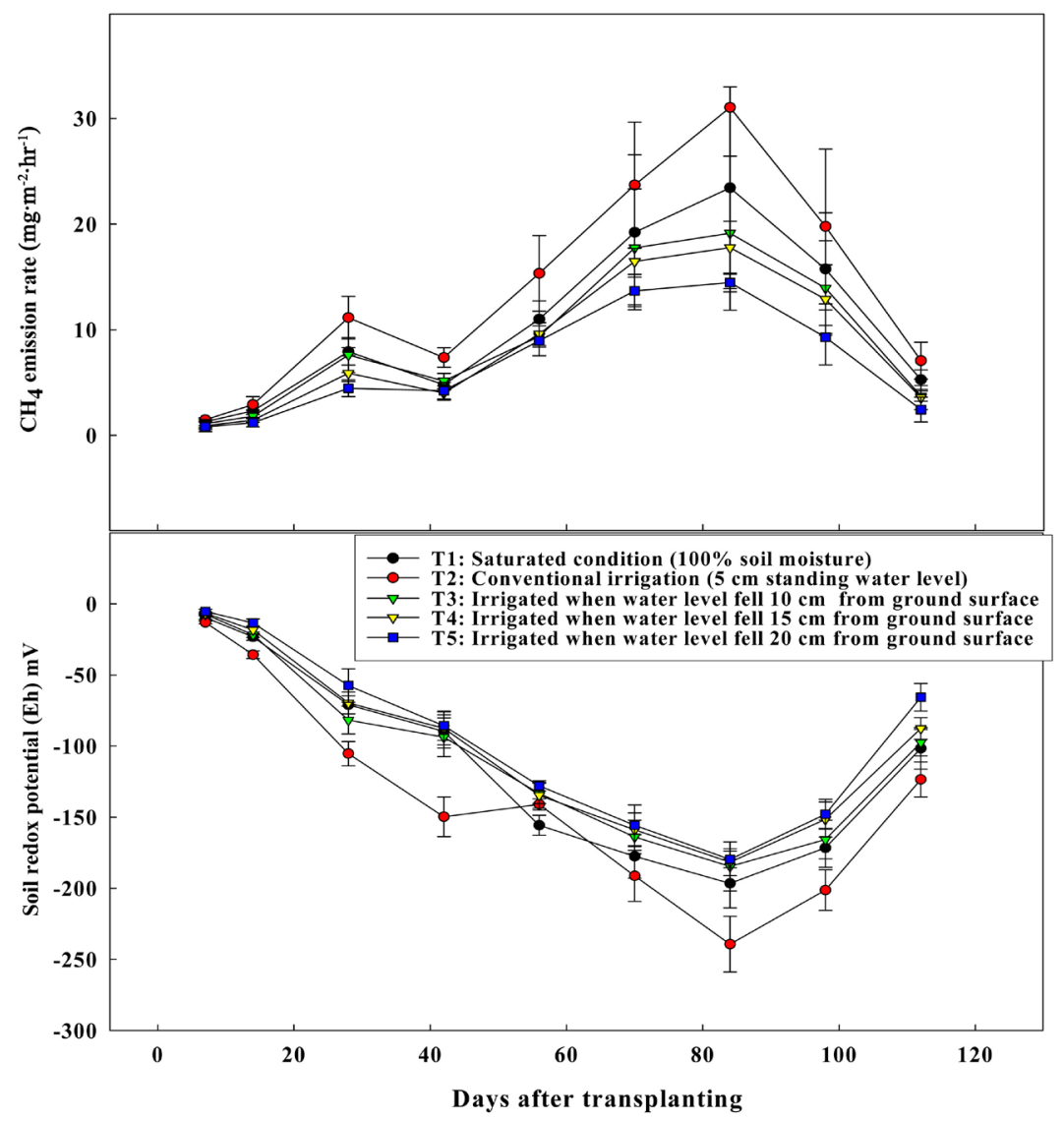

Figure 1. Changes in $\mathrm{CH}_{4}$ emission rate and soil redox status (Eh) under different irrigation treatments.

treatments which might be due to having capability of AWDI to improve the soil Eh of rice paddy soils. In study, $\mathrm{CH}_{4}$ emission was increased significantly with the development of soil reductive condition (Figure 1). When water supply was stopped before harvesting (after $84 \mathrm{DAT}$ ), the oxidation process was more for available oxygen that increased Eh values. The maximum and sharply decreased soil Eh value after tillering stage (42 DAT) from continuous flooded and saturated plots could be related to the development of anaerobic conditions and rapid decomposition of soil organic matter under waterlogged conditions. The intense reductive condition, e.g. soil Eh value -120 to -220 was noticed during reproductive stage which caused significant amount of $\mathrm{CH}_{4}$ emissions. AWDI significantly improved the soil redox potential status which ultimately decreased $\mathrm{CH}_{4}$ emissions during the entire rice growing period.

The highest $\mathrm{CH}_{4}$ emission rate was found in continuous flooded plots where aerenchyma tissue was well developed, probably due to waterlogging conditions (Figure 1). The most interesting phenomenon in this study is aerenchyma development in rice root during reproductive stage that was significantly influenced by different irrigation managements. The deficiency of oxygen mainly triggers root aerenchyma development which facilitates gas diffusion between roots and aerial environment. In study, AWDI plots showed less remarkable ae- 
renchyma for more availability of oxygen as like as $\mathrm{CH}_{4}$ emission influenced by different irrigation managements (Figure 2). Again, the formation and more intensity of aerenchyma development in continuous flooded and saturated plots might have accelerated the gas exchange rate between the rhizospheric soil environment and the atmosphere.

The decomposition rate of soil organic matter was more under irrigated field most probably due to the presence of available water. In study, the decomposition rate was more in continuous flooded plots that showed the highest $\mathrm{CH}_{4}$ emission among all treatments. AWDI plots showed more soil organic carbon due to less decomposition that might be for less water requirements (Figure 3). After heading stage, $\mathrm{CH}_{4}$ flux was decreased constantly due to lack of $\mathrm{CH}_{4}$ producing conditions caused by the end of irrigation and plant senescence, when labile organic $\mathrm{C}$ are no longer released due to the lack of water for decomposition.

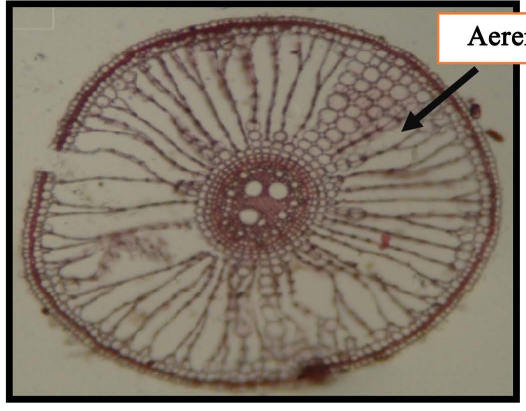

(a)

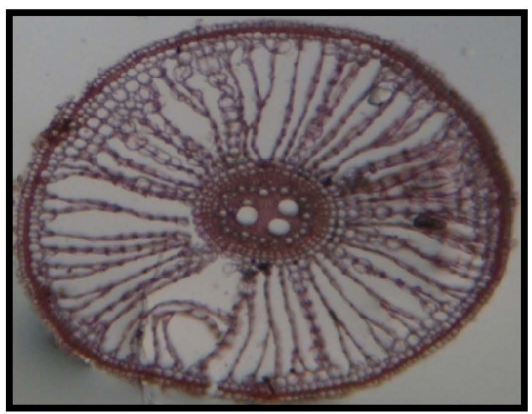

(c)

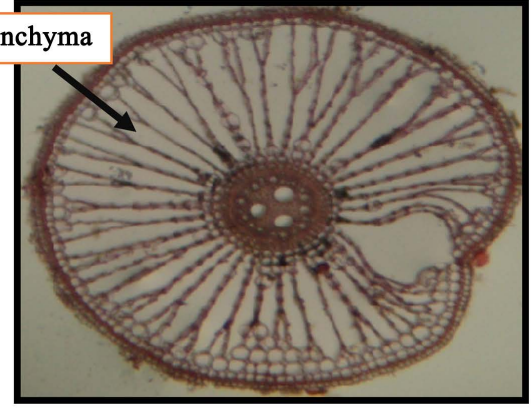

(b)

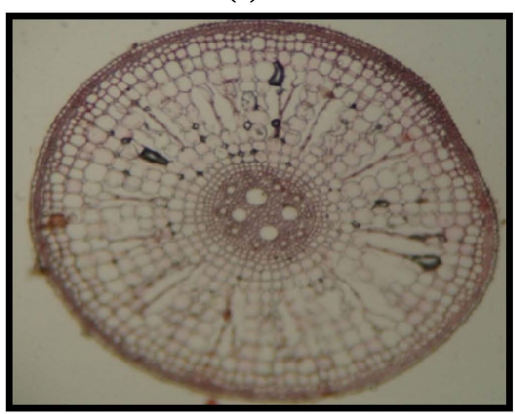

(d)

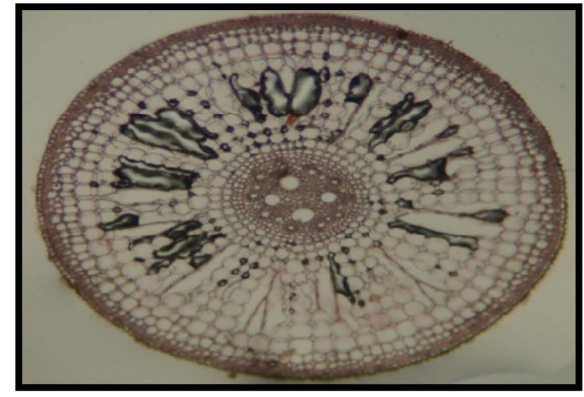

(e)

Figure 2. Development of aerenchyma tissue in rice root cortex at reproductive stage under different irrigation treatments. (a) Saturated conditions; (b) Continuous flooded; (c) AWDI, $10 \mathrm{~cm}$; (d) AWDI, $15 \mathrm{~cm}$; (e) AWDI, $20 \mathrm{~cm}$. 
1.2

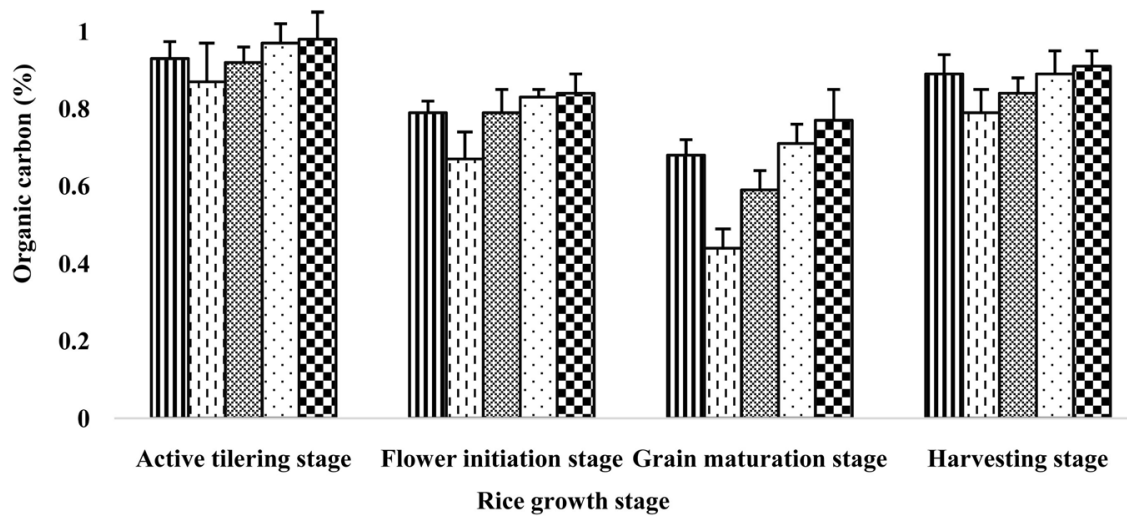

Figure 3. Changes in soil organic carbon with plant growth stages under different irrigation water management practices.

\subsection{Effect of Irrigation Managements on Rice Grain Yield and Water Productivity}

During first 2 weeks after transplantation, $5 \mathrm{~cm}$ standing water was maintained in all plots to avoid weed infestation. Water required for crop establishment was $62.6 \mathrm{~cm}$ and for land preparation was $45 \mathrm{~cm}$. Then, plots were irrigated according to treatments. Effective rainfall was $21.7 \mathrm{~cm}$. In study, the maximum 13 irrigations required for continuous flooded plots followed by saturated plots (10 irrigations) in where AWDI treatments $\mathrm{T}_{3}(10 \mathrm{~cm}), \mathrm{T}_{4}(15 \mathrm{~cm})$ and $\mathrm{T}_{5}(20 \mathrm{~cm})$ received 8,7 and 6 irrigations, respectively. The required water volume were 19,430 $\mathrm{m}^{3} \cdot \mathrm{ha}^{-1}, 17,930 \mathrm{~m}^{3} \cdot \mathrm{ha}^{-1}, 16,930 \mathrm{~m}^{3} \cdot \mathrm{ha}^{-1}, 16,430 \mathrm{~m}^{3} \cdot \mathrm{ha}^{-1}$ and $15,930 \mathrm{~m}^{3} \cdot \mathrm{ha}^{-1}$ for continuous flooded, saturated plot, AWDI- $10 \mathrm{~cm}$, AWDI-15 cm, AWDI- $20 \mathrm{~cm}$, respectively. Finally, it was found that AWDI- $20 \mathrm{~cm}$ could save highest amount (18\%) of irrigation water followed by AWDI-15 cm (16\%) and AWDI-10 cm (13\%) in where saturated plot could save only $8 \%$ irrigation water compared to continuous flooded plot.

The grain yield of rice was significantly increased by AWDIs. In present study, AWDI-10 cm gave the highest grain yield $\left(6250 \mathrm{~kg} \cdot \mathrm{ha}^{-1}\right)$ followed by AWDI-15 $\mathrm{cm}\left(5810 \mathrm{~kg} \cdot \mathrm{ha}^{-1}\right)$ but the lowest yield $\left(4283 \mathrm{~kg} \cdot \mathrm{ha}^{-1}\right)$ was found in AWDI-20 cm due to more water stress. Again, continuous flooded plots gave $5783 \mathrm{~kg} \cdot \mathrm{ha}^{-1}$ grain yield most probably for more waterlogged conditions throughout the growing season. Table 1 also shows the highest water productivity index $(0.369$ $\left.\mathrm{kg} \cdot \mathrm{m}^{-3}\right)$ was obtained in AWDI-10 $\mathrm{cm}$ followed by AWDI-15 $\mathrm{cm}\left(0.354 \mathrm{~kg} \cdot \mathrm{m}^{-3}\right)$, saturated plots $\left(0.299 \mathrm{~kg} \cdot \mathrm{m}^{-3}\right)$, continuous flooded plots $\left(0.298 \mathrm{~kg} \cdot \mathrm{m}^{-3}\right)$ and AWDI-20 cm $\left(0.269 \mathrm{~kg} \cdot \mathrm{m}^{-3}\right)$.

\subsection{Effect of Irrigation Managements on Seasonal $\mathrm{CH}_{4}$ Flux, GWP and GHGI}

The total GWP of $\mathrm{CH}_{4}$ significantly decreased with AWDI treatments as compared to continuous flooded plots. The total and highest GWP from the continuous 
Table 1. Rice grain yield, water productivity, water saving percentage, seasonal $\mathrm{CH}_{4}$ flux, GWPs and GHGI under different irrigation system.

\begin{tabular}{|c|c|c|c|c|c|c|}
\hline $\begin{array}{l}\text { Irrigation } \\
\text { system }\end{array}$ & $\begin{array}{c}\text { Grain } \\
\text { yield } \\
\left(\mathrm{kg} \cdot \mathrm{ha}^{-1}\right)\end{array}$ & $\begin{array}{c}\text { Water } \\
\text { productivity } \\
\left(\mathrm{kg} \cdot \mathrm{m}^{-3}\right)\end{array}$ & $\begin{array}{c}\text { Water } \\
\text { Savings } \\
(\%)\end{array}$ & $\begin{array}{c}\mathrm{CH}_{4} \text { flux } \\
\left(\mathrm{kg} \cdot \mathrm{ha}^{-1} \text { season }^{-1}\right)\end{array}$ & $\begin{array}{c}\mathrm{GWP}^{\mathrm{a}} \\
\left(\mathrm{Mg} \mathrm{CO}_{2} \mathrm{ha}^{-1}\right)\end{array}$ & $\mathrm{GHGI}^{\mathrm{b}}$ \\
\hline Saturated & $5365 c$ & $0.299 \mathrm{~b}$ & $8 \mathrm{~d}$ & $152.91 \mathrm{~b}$ & $3.82 \mathrm{~b}$ & $0.712 \mathrm{~b}$ \\
\hline $\begin{array}{c}\text { Continuous } \\
\text { flooded (Control) }\end{array}$ & $5783 \mathrm{~b}$ & $0.298 \mathrm{~b}$ & - & $206.43 \mathrm{a}$ & $5.16 \mathrm{a}$ & $0.892 \mathrm{a}$ \\
\hline AWDI $(10 \mathrm{~cm})$ & $6250 \mathrm{a}$ & $0.369 \mathrm{a}$ & $12 \mathrm{c}$ & $130.41 \mathrm{c}$ & $3.26 \mathrm{c}$ & $0.522 \mathrm{~d}$ \\
\hline AWDI $(15 \mathrm{~cm})$ & $5810 \mathrm{~b}$ & $0.354 \mathrm{a}$ & $16 \mathrm{~b}$ & $121.93 \mathrm{~d}$ & $3.05 \mathrm{~d}$ & $0.525 \mathrm{~d}$ \\
\hline AWDI $(20 \mathrm{~cm})$ & $4283 \mathrm{~d}$ & $0.269 \mathrm{c}$ & $24 \mathrm{a}$ & $101.72 \mathrm{e}$ & $2.54 \mathrm{e}$ & $0.593 \mathrm{c}$ \\
\hline $\begin{array}{c}\text { Level of } \\
\text { significance }\end{array}$ & * & * & $* *$ & * & * & * \\
\hline CV (\%) & 0.51 & 2.31 & 8.97 & 0.87 & 2.56 & 0.58 \\
\hline LSD & 52.95 & 0.01 & 1.85 & 2.32 & 0.17 & 0.06 \\
\hline
\end{tabular}

In a column, figures having similar letter(s) or no letters do not differ significantly whereas figures with dissimilar letter(s) differ significantly as per DMRT. ${ }^{* *}=$ Significant at $1 \%$ level of probability and ${ }^{*}=$ Significant at $5 \%$ level of probability. ${ }^{a} \mathrm{GWPof} \mathrm{CH}_{4}$ were calculated by multiplying 25 times on seasonal $\mathrm{CH}_{4}$ fluxes; The IPCC GWP factors (mass basis, $\mathrm{kg} \mathrm{CO}_{2}$-equivalent ha ${ }^{-1}$ ) for $\mathrm{CH}_{4}$ is 25 in the time horizon of 100 years (Froster et al., 2007); ${ }^{\mathrm{b}} \mathrm{GHGI}$ ( $\mathrm{kg} \mathrm{CO}_{2}$-equivalent $\mathrm{kg}^{-1}$ grain yield) was calculated by dividing GWPs of $\mathrm{CH}_{4}$ emissions by rice yield.

irrigated plot was $5.16 \mathrm{Mg} \mathrm{CO}_{2} \mathrm{ha}^{-1}$ followed by saturated plots $\left(3.82 \mathrm{Mg} \mathrm{CO}_{2}\right.$ $\mathrm{ha}^{-1}$ ). Conversely, under AWDI treatments the lowest GWP from the AWDI-20 $\mathrm{cm}$ was $2.54 \mathrm{Mg} \mathrm{CO}_{2} \mathrm{ha}^{-1}$ followed by AWDI-15 cm (3.05 $\left.\mathrm{Mg} \mathrm{CO}_{2} \mathrm{ha}^{-1}\right)$ and AWDI-10 cm (3.26 $\left.\mathrm{Mg} \mathrm{CO}_{2} \mathrm{ha}^{-1}\right)$. In general, intermittent irrigation system (AWDI) significantly reduced the total GWPs (Table 1), even though continuous flooded and saturated plots showed two-fold higher GWPs. The GHGI also decreased remarkably with AWDI treatments compared to other treatments. As a result, AWDI-20 cm reduced highest percentage (50\%) of $\mathrm{CH}_{4}$ emission rate but gave lower yield due to more water stress compared to continuous flooded plots. AWDI- $15 \mathrm{~cm}$ could reduce $40 \% \mathrm{CH}_{4}$ emission with satisfactory yield although AWDI- $10 \mathrm{~cm}$ reduced only $36 \% \mathrm{CH}_{4}$ emission with the highest grain yield production.

\subsection{Effect of Irrigation Managements on Nutrient Status Prior to Rice Harvesting Stage}

In study, Table 2 shows that the intermittent AWDI system increased soil porosity, the content of soil organic matter compared to continuous irrigated control plots in where total $\mathrm{N}$ content, available $P$ and $\mathrm{K}$ content showed non-significant variation under different irrigation treatments. AWDI did not affect the soil nutrient status in addition, increased organic carbon as like as soil organic matter status. Soil organic matter significantly varied from $2.10 \%$ to $1.90 \%$ in where the highest \% OM was found in AWDI-15 cm and the lowest was in continuous flooded plots. 
Table 2. Chemical properties of soil prior to rice harvesting stage.

\begin{tabular}{cccccccc}
\hline Irrigation System & $\begin{array}{c}\text { Soil } \\
\text { porosity }\end{array}$ & $\begin{array}{c}\text { Soil } \\
\mathrm{pH}\end{array}$ & Soil Eh & $\begin{array}{c}\text { Organic } \\
\text { matter }(\%)\end{array}$ & $\begin{array}{c}\text { Total } \\
\mathrm{N}(\%)\end{array}$ & $\begin{array}{c}\text { Available } \\
P(\mathrm{ppm})\end{array}$ & $\begin{array}{c}\mathrm{K} \\
(\mathrm{meq} / 100 \mathrm{~g})\end{array}$ \\
\hline Saturated & 0.54 & 6.7 & -57.71 & 1.97 & 0.12 & 13.92 & 0.12 \\
Continuous flooded & 0.52 & 6.8 & -66.6 & 1.74 & 0.10 & 12.56 & 0.12 \\
AWDI $(10 \mathrm{~cm})$ & 0.57 & 6.6 & -43.5 & 2.07 & 0.14 & 14.17 & 0.13 \\
AWDI $(15 \mathrm{~cm})$ & 0.57 & 6.62 & -31.6 & 2.10 & 0.13 & 13.66 & 0.12 \\
AWDI $(20 \mathrm{~cm})$ & 0.59 & 6.52 & -27.32 & 1.99 & 0.12 & 13.24 & 0.11 \\
Level of significance & $*$ & $\mathrm{NS}$ & $* *$ & $*$ & $*$ & $*$ & $\mathrm{NS}$ \\
CV $(\%)$ & 2.18 & 3.53 & 21.77 & 8.87 & 22.22 & 6.43 & 15.21 \\
LSD & 0.59 & 0.22 & 3.8 & 0.13 & 0.02 & 1.04 & 0.02 \\
\hline
\end{tabular}

${ }^{*}=$ Significant at $1 \%$ level of probability; ${ }^{*}=$ Significant at $5 \%$ level of probability and NS = Not significant.

\subsection{Correlations Correlation of $\mathrm{CH}_{4}$ Emissions with Other Parameters}

There were negative correlations between total seasonal $\mathrm{CH}_{4}$ flux with grain yield, water productivity index, soil Eh, organic matter, total $\mathrm{N}$, available $P$ and $\mathrm{K}$ content except no. of irrigation, total volume of water supplied for rice grain production, soil porosity and soil $\mathrm{pH}$ under continuous irrigated treatment (Table 3). On the other hand, $\mathrm{CH}_{4}$ flux showed a strong positive correlation with no. of irrigations, total volume of water supplied for paddy field, grain yield, water productivity index, the availability of soil organic matter, soil $\mathrm{pH}$, total $\mathrm{N}$, available $P$ and $\mathrm{K}$ content, while there were only negative correlation with soil Eh and soil porosity under AWDI systems.

\section{Discussion}

In study, Alternate Wetting and Drying Irrigation (AWDI) significantly decreased the seasonal $\mathrm{CH}_{4}$ emissions during rice cultivation. The lower $\mathrm{CH}_{4}$ emission from AWDI plots was due to increased aeration, stabilization of soil organic carbon, improved soil redox potential status. Among AWDI treatments, $\mathrm{T}_{3}(10$ $\mathrm{cm}$ ) reduced $36 \% \mathrm{CH}_{4}$ flux followed by $\mathrm{T}_{4}-15 \mathrm{~cm}(40 \%)$ and $\mathrm{T}_{5}-20 \mathrm{~cm}(50 \%)$. This result revealed that AWDI treatments are the most effective options for reducing $\mathrm{CH}_{4}$ emission during Boro rice cultivation, which was consistent with the findings of Jain et al. (2013). This result might be also due to highly promoting soil reduced condition that was influenced by different irrigation treatments (Supparattanapan et al., 2009). Ali et al. (2013) also reported that intermittent irrigations significantly reduced total seasonal $\mathrm{CH}_{4}$ emissions by $27 \%$ compared to conventional (124 $\mathrm{kg} \mathrm{CH}_{4} / \mathrm{ha}$ ) irrigated rice paddy field.

The increased Eh values might have suppressed the methanogens' activities that were responsible for $\mathrm{CH}_{4}$ emission from rice field, while stimulated the methanotrophs activities, and eventually decreased methane emission rate during rice cultivation (Ali, 2008). On the other hand, the highest $\mathrm{CH}_{4}$ emission rate 
Table 3. Correlation of $\mathrm{CH}_{4}$ emissions with selected plant parameters and soil properties.

\begin{tabular}{ccc}
\hline \multirow{2}{*}{ Parameters } & \multicolumn{2}{c}{ Correlation coefficient $(\mathrm{r})$} \\
\cline { 2 - 3 } & Saturated + Continuous & AWDIs \\
\hline Grain yield & -0.547 & 0.585 \\
Water productivity & -0.754 & 0.444 \\
Soil pH & 0.309 & 0.009 \\
Soil Eh & -0.918 & -0.794 \\
Soil porosity & -0.712 & -0.782 \\
Organic matter & -0.772 & 0.309 \\
Total N & -0.997 & 0.292 \\
Available $P$ & -0.385 & 0.062 \\
K & -0.883 & 0.311 \\
\hline
\end{tabular}

was found in continuous flooded plots due to more conductivity of $\mathrm{CH}_{4}$ gas through aerenchyma channel, more decomposable organic carbon and highly soil reduced status under waterlogged condition. Tarlera et al. (2016) also observed more $\mathrm{CH}_{4}$ emission rate in the treatment of continuous flooding than AWDI treatment. In the present study, although saturated plots showed low $\mathrm{CH}_{4}$ emission than continuous irrigated control plots but always gave high rate of $\mathrm{CH}_{4}$ emission than AWDI treatments.

The seasonal $\mathrm{CH}_{4}$ emissions gave more or less similar pattern in both cultivation systems, i.e. $\mathrm{CH}_{4}$ flux was higher during reproductive stage of rice growth in all treatments due to the development of root aerenchyma (Kludge et al., 1993), and decomposition of soil organic materials (Dubey, 2005). The sudden and sharp fall in $\mathrm{CH}_{4}$ emission rates at grain maturation stage in all might be due to the aging of rice plant, the end of irrigation and plant senescence, when labile organic $\mathrm{C}$ are no longer released by organic matter decomposition due to lack of available water that was also supported by Cai et al. (1997). Finally, AWDI treatments significantly could mitigate the rate of $\mathrm{CH}_{4}$ emission upto $50 \%(20$ $\mathrm{cm}), 40 \%(15 \mathrm{~cm})$ and $36 \%(10 \mathrm{~cm})$ from that of continuous flooding in a cropping season which was supported by Win et al. (2015) and Itoh et al. (2011).

In our experiment, AWDI- $20 \mathrm{~cm}$ saved upto $18 \%$ irrigation water with the lowest $\mathrm{CH}_{4}$ emission rate compared to continuous flooded treatment but gave lower yield due to more water stress. But AWDI- $10 \mathrm{~cm}$ and $15 \mathrm{~cm}$ saved upto $13 \%$ and $16 \%$ irrigation water, respectively with minimum rate of $\mathrm{CH}_{4}$ emission compared to continuous flooded treatment as supported by Chapagain and Yamaji (2010). Yang et al. (2016) also reported that moderate AWDI-in which photosynthesis was not severely inhibited and plants could rehydrate overnight, during soil drying period or when water table was maintained at 10 to $15 \mathrm{~cm}$ below soil surface, could increase not only WUE but also grain yield.

AWDI treatments stimulated the more rice yield, which were negatively interlinked with total seasonal $\mathrm{CH}_{4}$ flux in where more root depth was found most 
probably for the more soil porosity that supported more tillers and ultimately more yield of rice. This might be due to more depth of rice root support more nutrient uptake from different soil nutrient layer. Rice grain yield was increased by $11 \%$, only in AWDI $(10 \mathrm{~cm})$ in where AWDI $(15 \mathrm{~cm})$ gave more or less similar grain yield over the control irrigated plots in our experiment. Conversely, rice grain yield was negatively correlated with seasonal $\mathrm{CH}_{4}$ flux, which was supported by Denier van Der Gon et al. (2002). Among the all treatments, AWDI $(10 \mathrm{~cm})$ and AWDI $(15 \mathrm{~cm})$ are economically feasible and effective for mitigating seasonal $\mathrm{CH}_{4}$ flux and increasing rice productivity over the conventional flooded rice cultivation.

\section{Conclusion}

This field experiment confirmed that AWDI is a promising method which provides duel benefits of water saving and optimum rice productivity with low $\mathrm{CH}_{4}$ emission compared to conventional flood irrigation during dry season Boro rice cultivation. Conclusively, suitable alternate wet and dry irrigation water management practices (Irrigate when water level falls below $10-15 \mathrm{~cm}$ from surface) could be implemented in farmers' field based on site specific agro-ecological zone for significant water savings, reducing methane emission and sustaining rice productivity. Further field trials in different agro-ecological zones may provide wider adaptability and farmers' acceptability.

\section{Acknowledgements}

The authors are highly grateful to the National Science and Technology, Ministry of Science and Technology, 2015-2016, Government of the People's Republic of Bangladesh for financial support after this research.

\section{Conflicts of Interest}

There is no conflict of interest for this research publication.

\section{References}

Ali, M. A. (2008). Effect of Soil Amendments Having Electron Acceptors for Mitigating Methane Emission during Rice (Oryza sativa) Cultivation. Ph.D. Thesis, Jinju: Division of Applied Life Science, Gyeongsang National University.

Ali, M. A., Haque, M. A., \& Kim, P. J. (2013). Mitigating Global Warming Potentials of Methane and Nitrous Oxide from Rice Farming in Bangladesh. AMBIO, 42, 357-368. https://doi.org/10.1007/s13280-012-0349-3

Ali, M. A., Oh, J. H., \& Kim, P. J. (2008). Evaluation of Silicate Iron Slag Amendment on Reducing Methane Emission from Flood Water Rice Farming. Journal of Agriculture, Ecosystem and Environment, 128, 21-26. https://doi.org/10.1016/j.agee.2008.04.014

Bangladesh Rice Research Institute (BRRI) (2016). Alternate Wetting and Drying (AWD) Method. Bangladesh Rice Knowledge Bank (BRKB).

BBS (Bangladesh Bureau of Statistics) (2012). Statistical Year Book of Bangladesh 2012: Bangladesh Bureau of Statistics. Dhaka: Stat. Div., Min. Plan. Govt. People’s Repub. 
Bhuiyan, S. I. (1992). Water Management in Relation to Crop Production: Case Study on Rice. Outlook on Agriculture, 21, 293-299.

https://doi.org/10.1177/003072709202100408

Brown, J. D., \& Lilleland (1946). Rapid Determination of Potassium and Sodium in Plant Material and Soil Extracts by Flame Photometry. Proceeding of the American Society of Horticultural Sciences, 48, 341-346.

Cai, Z., Xing, G., Yan, X., Xu, H., Tsuruta, H., Yagi, K., \& Minami, K. (1997). Methane and Nitrous Oxide Emissions from Paddy Fields as Affected by Nitrogen Fertilizers and Water Management. Journal of Plant Soil, 196, 7-14.

https://doi.org/10.1023/A:1004263405020

Chapagain, T., \& Yamaji, E. (2010). The Effects of Irrigation Method, Age of Seedling and Spacing on Crop Performance, Productivity and Water-Wise Rice Production in Japan. Paddy and Water Environment, 8, 81-90. https://doi.org/10.1007/s10333-009-0187-5

Conrad, R. (2002). Control of Microbial Methane Production in Wetland Rice Fields. Nutrient Cycling in Agro-Ecosystems, 64, 59-69. https://doi.org/10.1023/A:1021178713988

Denier van Der Gon, H. A. C., Kropff, M. J., van Breemen, N., Wassmann, R., Lantin, R. S., Aduna, E., \& Corton, T. M. (2002). Optimizing Grain Yields Reduces $\mathrm{CH}_{4}$ Emissions from Rice Paddy Fields. Proceedings of the National Academy of Sciences of the United States of America, 99, 12021-12024. https://doi.org/10.1073/pnas.192276599

Dubey, S. K. (2005). Microbial Ecology of Methane Emission in Rice Agro-Ecosystem: A Review. Applied Ecology and Environmental Research, 3, 1-27. https://doi.org/10.15666/aeer/0302_001027

Itoh, M., Sudo, S., Mori, S., Saito, H., Yoshida, T., Shiratori, Y., Suga, S., Yoshikawa, N., Suzue, Y., Mizukami, H., Mochida, T., \& Yagi, K. (2011). Mitigation of Methane Emissions from Paddy Fields by Prolonging Midseason Drainage. Agricultural and Ecosystems Environment, 141, 359-372. https://doi.org/10.1016/j.agee.2011.03.019

Jaafar, M. N., Saad, P., \& Vel Arjunan, S. N. (2000). A Computational Model for Water Use Efficiency in Rice Production. Jurnal Teknologi Maklumat, 12, 1-13.

Jain, N., Dubey, R., Dubey, D. S., Singh, J., Khanna, M., Pathak, H., \& Bhatia, A. (2013). Mitigation of Greenhouse Gas Emission with System of Rice Intensification in the Indo-Gangetic Plains. Paddy and Water Environment, 12, 355-363. https://doi.org/10.1007/s10333-013-0390-2

Kludge, H. K., Delaune, R. D., \& Patrick Jr., W. H. (1993). Aerenchyma Formation and Methane and Oxygen Exchange in Rice. Soil Science Society of America Journal, 57, 386-391. https://doi.org/10.2136/sssaj1993.03615995005700020017x

Mosier, A. R., Halvorson, A. D., Reule, C. A., \& Liu, X. J. (2006). Net Global Warming Potential and Greenhouse Gas Intensity in Irrigated Cropping Systems in Northeastern Colorado. Journal of Environmental Quality, 35, 1584-1598.

https://doi.org/10.2134/jeq2005.0232

Nieder, R., \& Benbi, D. K. (2008). Bidirectional Biosphere-Atmosphere Interactions. In Carbon and Nitrogen in the Terrestrial Environment (pp. 235-305). Berlin: Springer Science + Business Media B.V. https://doi.org/10.1007/978-1-4020-8433-1_8

Olsen, S. R., Cole, C. U., Watanable, F. S., \& Deun, L. A. (1954). Estimation of Available P in Soil Extraction with Sodium Bicarbonate (p. 929). U.S. Dept. of Agric. Cir.

Page, A. L., Miller, R. H., \& Keeney, D. R. (1982). Methods of Soil Analysis, Part 2 (2nd ed.). Madison WI: American Society of Agronomy.

Price, A. H., Norton, G. J., Salt, D. E., Ebenhoeh, O., Meharg, A. A., Meharg, C.,Islam, M. 
R., Sarma, R. N., Dasgupta, T., Ismail, A. M., Mcnally, K. L., Zhang, H., Dodd, I. C., \& Davies, W. J. (2013). Alternate Wetting and Drying Irrigation for Rice in Bangladesh: Is It Sustainable and Has Plant Breeding Something to Offer? Food and Energy Security, 2, 120-129. https://doi.org/10.1002/fes3.29

Quassem, M. A. (2010). The Daily Star. 22 August, Newspaper, Bangladesh.

Rashid, M. H. (1997). Manual on Irrigation and Soil-Water Engineering. Joydebpur: Irrigation and Water Management Division, Bangladesh Agricultural Research Institute.

Rolston, D. E. (1986). Gas Flux. In A. Klute (Ed.), Methods of Soil Analysis (Part 1, 2nd ed., pp. 1103-1119). Agron. Monogr. 9, Madison, WI: Soil Sci. Soc. America and America Soc. Agron. https://doi.org/10.2136/sssabookser5.1.2ed.c47

Singh, S., Singh, J. S., \& Kashyap, A. K. (1999). Methane Flux from Irrigated Rice Fields in Relation to Crop Growth and N-Fertilization. Soil Biology and Biochemistry, 31, 1219-1228. https://doi.org/10.1016/S0038-0717(99)00027-9

Smith, M. (1992). CROPWAT-A Computer Programme. Irrigation Planning and Management. FAO Irrigation and Drainage Paper 46. Rome.

Solomon, S., Qin, D., Manning, M., Alley, R. B., Berntsen, T., Bindoff, N. L., Chen, Z., Chidthaisong, R., Tignor, M. L., \& Miller, H. (2007). The Physical Science Basis. In Contribution of Working Group I to the Fourth Assessment Report of Intergovernmental Panel on Climate Change (pp. 20-91). New York, Cambridge: Cambridge University Press.

Supparattanapan, S., Saenjan, Cecile, Q., Maeght, J. L., \& Olivier, G. (2009). Salinity and Organic Amendment Effects on Methane Emission from a Rain-Fed Saline Paddy Field. Soil Science and Plant Nutrition, 55, 142-149. https://doi.org/10.1111/j.1747-0765.2008.00330.x

Tarlera, S., Capurro, M. C., Irisarri, P., Scavino, A. F., Canton, G., \& Roel, A. (2016). Yield-Scaled Global Warming Potential of Two Irrigation Management Systems in a Highly Productive Rice System. Scientia Agricola (Piracicaba, Braz.), 73, 43-50. https://doi.org/10.1590/0103-9016-2015-0050

Uphoff, N., \& Kassam, A. (2009). A Case Study: The System of Rice Intensification, Agricultural Technologies for Developing Countries. Annex 3, Science and Technology Options Assessment (STOA), European Parliament.

Walkley, \& Black, C. A. (1965). An Examination of Digtiareff Method for Determining Soil Organic Matter and Proposed Modification for the Chronic Acid Titration Method. Soil Science, 37, 29-38. https://doi.org/10.1097/00010694-193401000-00003

Win, K. T., Nonaka, R., Win, A. T., Sasada, Y., Toyota, K., \& Motobayashi, T. (2015). Effects of Water Saving Irrigation and Rice Variety on Greenhouse Gas Emissions and Water Use Efficiency in a Paddy Field Fertilized with Anaerobically Digested Pig Slurry. Paddy and Water Environment, 13, 51-60. https://doi.org/10.1007/s10333-013-0406-y

Yang, J., Zhou, Q., \& Zhang, J. (2016). Moderate Wetting and Drying Increases Rice Yield and Reduces Water Use, Grain Arsenic Level and Methane Emission. The Crop Journal, 5, 151-158. https://doi.org/10.1016/j.cj.2016.06.002

Zheng, X. H., Zou, J. W., Huang, Y., \& Wang, Y. S. (2007). Quantifying Direct $\mathrm{CH}_{4}$ Emissions in Paddy Fields during Rice Growing Season in Mainland China: Dependence on Water Regime. Atmospheric Environment, 41, 8030-8042.

https://doi.org/10.1016/j.atmosenv.2007.06.049 